\title{
Burnout and labour aspects in the nursing teams at two medium- sized hospitals ${ }^{1}$
}

\author{
Flávia Maria de França² \\ Rogério Ferrari ${ }^{3}$ \\ Diana Carla Ferrari ${ }^{4}$ \\ Elioenai Dornelles Alves ${ }^{5}$
}

Purpose: The aim of this study is to identify the occurrence of Burnout Syndrome (BS) and assess its relationship with different labour-related aspects, among nursing professionals at two medium-sizes hospitals in the city of Cáceres. Method: This is a transversal and descriptive study, with a sample totalling 141 subjects. As an instrument of research, we used a questionnaire for the limitation of labour-related aspects, with the addition of the Maslach Burnout Inventory (MBI). Results: Out of the 141 professional people considered, 13 had BS, according to the MBI. In relation to the different labour aspects, the professional people most affected were those with: work regime based on pay by the day, a working week of 30 hours, regularly hired, with double employment, lower graduation period, less time spent at the unit, and active in the administrative segment. Conclusions: Hence, there was the demonstration of the presence of BS within the sample, showing the need for the proposal of organisational changes within the working environment so as to reduce these factors and their interference on the health of the worker.

Descriptors: Burnout, Professional; Nursing, Team; Occupational Health.

\footnotetext{
${ }^{1}$ Paper extrated from Master's Thesis "Estudo sobre síndrome de Burnout em profissionais de enfermagem em dois hospitais de médio porte no município de Cáceres-MT", presented to Universidade de Brasília, Brazil.

2 RN, MSc, Hospital Regional de Cáceres, Brazil. Professor, Departamento de Enfermagem, Universidade do Estado de Mato Grosso, Brazil.

${ }_{3}^{3}$ Undergraduate student in Medicine, Universidade Estácio de Sá, Campus Centro V - Arcos da Lapa, Rio de Janeiro, Brazil.

${ }^{4} \mathrm{RN}$.

${ }^{5}$ PhD, Full Professor, Departamento de Enfermagem, Faculdade de Ciências da Saúde, Universidade de Brasília, Brazil.
}

Corresponding Author:

Flávia Maria de França

Universidade do Estado de Mato Grosso. Departamento de Enfermagem

Av. São João, s/n

Bairro: Cavalhada

CEP: 78.200-000, Cáceres, MT

E-mail: flavia43franca@hotmail.com 


\section{Burnout e os aspectos laborais na equipe de enfermagem de dois hospitais de médio porte}

Objetivo: identificar a incidência da Síndrome de Burnout (SB) e avaliar sua relação com os aspectos laborais, em profissionais de enfermagem de dois hospitais de médio porte de Cáceres, MT. Método: trata-se de estudo descritivo, transversal, com amostra de 141 sujeitos. Como instrumento de pesquisa utilizou-se um questionário para o delineamento dos aspectos laborais, acrescido do Maslach Burnout Inventory (MBI). Resultados: dos 141 profissionais, 13 apresentaram SB, segundo o MBI. Em relação aos aspectos laborais, os profissionais mais acometidos foram aqueles com regime de trabalho diarista, 30 horas semanais de serviço, contratado, duplo emprego, menor tempo de formação, pouco tempo na unidade e atuantes no setor administrativo. Conclusões: logo, demonstrou-se a presença da SB na amostra, revelando necessidade de se propor mudanças organizacionais no ambiente de trabalho, a fim de diminuir a interferência desses fatores na saúde do trabalhador.

Descritores: Estresse Ocupacional; Equipe de Enfermagem; Saúde do Trabalhador.

\section{Burnout y aspectos laborales del personal de enfermería de dos hospitales de medio portea}

Objetivo: Identificar la incidencia de síndrome de Burnout (BS) y evaluar su relación con los aspectos laborales, personal de enfermería de dos hospitales de medio portea de Cáceres. Método: Se trata de un estudio descriptivo, de corte transversal de la muestra de 141 sujetos. Como instrumento de investigación se utilizó un cuestionario para el delineamiento de los aspectos laborales, aumentando del Maslach Burnout Inventory (MBI). Resultados: De los 141 profesionales, 13 presentaron SB según MBI. Con relación con los aspectos laborales los profesionales más acometidos son aquéllos con: régimen de trabajo diarista, 30 horas semanales de servicio, contratado, doble empleo, menor tiempo formación, poco tiempo en la unidad y actuación en el sector administrativo. Conclusiones: Luego, se demostró la presencia de SB en la muestra, revelando necesidad de proponerse cambios organizacionales en el ambiente de trabajo a fin de apocar estos factores interfieren en la salud del trabajador.

Descriptores: Agotamiento Profesional; Grupo de Enfermería; Salud Laboral.

\section{Introduction}

Professional experience in caretaking leads to growing emotional tension, attention, and also major responsibilities with each gesture. This is the nature of work in the health segment, because it results from dealing with situations of pain and suffering, and even with the deaths of patients, which could affect those who work in hospitals, leading to the appearance of Burnout Syndrome (BS).

Burnout is a syndrome where the worker loses the sense of his or her relationship with work, meaning that things are no longer important. This is a multidimensional concept that involves three main components, which can appear associated yet are independent: emotional exhaustion; depersonalisation and low personal accomplishment at work ${ }^{(1-2)}$.

Emotional exhaustion can be characterised by an absence or a lack of energy, together with a feeling of emotional fatigue. Workers realise that they are not able to spend any more energy to meet the needs of their clients, or even other people, as has happened in situations in the past.

In relation to Depersonalisation, this can be defined as a greater emotional distance, indifference regarding work activities, and even the worker treating other 
people as objects(2). Each worker finds ways to coexist and also to release the tension generated by the rupture between getting involved or not, within the workplace environment.

Finally, low professional accomplishment can be characterised by a general feeling of insufficiency, low self-esteem, dissatisfaction with their activities, and demotivation, often causing a wish to abandon the profession ${ }^{(3)}$. People do not feel happy with themselves and also not satisfied with their professional developments ${ }^{(4-5)}$.

Burnout appears as a response to chronic stress, directly affecting the performance of tasks, interpersonal relationships, productivity and even the quality of life at work, of the individual and even of the organisation as a whole, due to the direct exposure to patients, and the long working hours, often under unfavourable conditions $^{(6)}$.

It is therefore a syndrome which is characteristic of the working environment, resulting from the chronification of occupational stress, and can have serious negative consequences at individual, professional, family, social and institutional level. Among the consequences brought by this syndrome to the health care institution, we can mention the high rates of absenteeism, which consequently has a bearing on concerns for these organisations.

Nurses, technicians and nursing assistants are all part of a profession which has, in its very essence, the responsibility of caring and which has much of its workload taken up with direct contact with patients and also with patients' families. From the standpoint of work organisation, the indefinition of the professional role; the excess workload which is often justified with allegations of lack of personnel and encouraged through the payment of overtime; the lack of independence and authority when taking decisions, among others, generate a state of chronic stress, this being identified as one of the professions which has the greatest occurrence of burnout ${ }^{(7-8)}$. This fact justifies the choice of this professional class for this research study, as it is considered a profession with a risk of development of this syndrome.

Apart from the characteristics of the daily routine of the nursing profession, which makes the professionals highly prone to burnout, as mentioned above, we must also mention that the work location of the nursing professional may also have an influence on the onset of this syndrome. The activities of hospital work can be characterised by an excessive workload, contact with situations pushing strain to the limit, high levels of tension and also risk, for self and others ${ }^{(9)}$.

The workloads of the nursing professionals tend to be exhausting, due to the volume of users, and the replenishment of the energy of these workers is not always adequate. The professionals of this area are subjected to on-call duty periods which, especially when at night, play havoc with the biorhythms governing sleep, meal times and social activities. Another point is that these professionals often dedicate themselves to more than one job, as the salaries in this segment tend to be low and the pace of work in emergency situations never lets them go unpunished ${ }^{(10)}$.

In the light of this fact, we mention the relevance of the choice of the hospital unit as the field of our study, considering the importance of investigating the work aspects associated to the health of nursing workers in the hospital network, as the environment is a constant source of stress-producing factors which could jeopardise the service provided.

We therefore consider it essential to reflect and develop studies about this theme, to better understand the factors that contribute to the health/illness process for workers in the nursing career, in hospital units. ${ }^{(11)}$

Thus, in the light of the above, this study has sought to gauge the occurrence of Burnout Syndrome and its relationship with labour aspects of nursing professionals at the Dr Antônio Fontes Regional Hospital and the São Luiz Hospital, both located in the municipality of Cáceres, State of Mato Grosso, Brazil.

\section{Method}

This is a descriptive quantitative epidemiological study of the transversal variety, with an approach to Burnout Syndrome based on the work-related aspects among nursing professionals from the hospital network.

The setting of this study was two medium-sized hospitals in the city of Cáceres, State of Mato Grosso, Brazil: the Dr Antônio Fontes Regional Hospital at Cáceres (HRCAF) and the São Luiz Hospital (HSL). Here we mention that Cáceres is an important regional health hub covering 22 municipalities of the region, serving a combined population of more than 185 thousand users of the Brazilian Single Health System (Sistema Único de Saúde - SUS)(12). The choice of the hospitals occurred due to them being references in medical services of medium to high complexity, and also due to the support they have given to teaching and research in the health 
area, having partnership agreements with Universities and technical learning institutions such as the University of the State of Mato Grosso (Universidade do Estado de Mato Grosso - UNEMAT), the University of Quatro Marcos (Faculdade de Quatro Marcos - FQM) and the Cáceres Educational Institute (Instituto Educacional de Cáceres - IEC). Here it is very important to check the burnout syndrome among nursing professionals who provide assistance in these two hospitals of regional reference.

HRCAF is a state-owned Government hospital and is a benchmark reference in the South-western part of the State of Mato Grosso for urgent and emergency treatment, meeting the demand of 22 municipalities in the region. The HSL is a private institution and is accredited for use by the SUS, being a reference for: general medical practice, general surgery, clinical and surgical obstetrics, and also a Type II Intensive Care Unit (ICU) for adults.

The sample of the present study was obtained by the method of convenience sampling, consisting of 141 professionals of the nursing segment, at three hierarchical levels: nursing assistant, nursing technician and nurse.

The nursing team from HCAF, according to the Human Resources department, is made up of 141 professional people in the nursing sector (22 nurses, 73 nursing technicians and 46 nursing assistants). However, using the criteria for exclusion, there remained a group of 89 professional people, participating in the study at HRCAF (16 nurses, 55 nursing technicians and 46 nursing assistants). At HSL the nursing team has 144 nursing professionals (21 nurses, 89 technicians and 34 nursing assistants). However, the distribution of the professional people participating in the study at HSL after the criteria of exclusion have been applied consisted of 52 people (14 nurses, 31 nursing technicians and 6 nursing assistants). This, the sample ended up with 141 participating people, consisting of 89 professionals from HRCAF and 52 from HSL.

For inclusion in the study, the main criterion adopted for selection was that of taking all professional people in active service who agreed to participate in this research, on a voluntary basis. The criteria for exclusion included those on holiday or special leave, on sick leave, maternity leave, and those off work for professional training, such as master's and doctorate courses.

As a research instrument, two questionnaires were applied. The first, for establishment of social and demographic aspects and work features, had 14 closed questions and was prepared based on dichotomous variables, attributes and also continuous variables.

The dichotomic variables included sex, working day, double employment. Attribute variables included: area of work at the hospital, professional category, educational level, weekly workload and contract of employment. Finally, continuous variables were such as age bracket, time working at the unit and time of qualification.

The second questionnaire refers to the Maslach Burnout Inventory (MBI) used to assess burnout, and has 22 questions in its adapted version, validated for the Portuguese language by Tamayo ${ }^{(13)}$. The MBI is self-informative and shall be answered on a five-point frequency scale from 1 (never) to 5 (always). The 22 items of the inventory assess the three mutually independent dimensions, namely: Emotional Exhaustion (9 items), Depersonalisation (5 items) and Professional Accomplishments (8 items).

The points in each subscale were obtained by adding the respective values. For this, we used the cut-off scores of another similar study as executed, in which the authors (7) considered that on the subscale for Emotional Exhaustion (EE) a score of 27 or more would suggest a high level of exhaustion, while 19 to 26 could be moderate values and point scores less than 19 would indicate a low level of EE.

In the case of Depersonalisation (DE), a point score of 10 or more would be high; between 6 and 9 would be moderate; and below 6 would show a low degree of depersonalisation.

The subscale of Professional Accomplishment (RP) has an inverted scale: a high level would have scores up to 33; a medium level would have point scores between 34 and 39, and a low level would correspond to scores over 40.

The information from the answered instruments were encoded, keyed in and then processed on an Excel ${ }^{\circledR}$ spreadsheet. All analysis was made using the statistical software known as SPSS ${ }^{\circledR}$ (Social Package for the Social Sciences), version 15.0 for Windows $\AA$.

The results were analysed using descriptive statistics of the data (mean, standard deviation, median, percentage and incidence) and presented in tabular form, using the resources of SPSS 15.0.

To compare the variables, the non-parametric chisquare test $\left(\mathbf{X}^{2}\right)$ has been applied, with a significance level of $5 \%$ probability $(\rho<0.05)$.

The present study was developed with the acquiescence of the hospitals concerned and also approved by the Ethics Committee for Research with 
Human Subjects of the Faculty of Health Sciences of the University of Brasília on 8 June 2010, with opinion statement number 052/10.

\section{Results}

In relation to social and demographic characteristics, most of the subjects were female $(84.40 \%)$, married $(58.15 \%)$, with children $(75.90 \%)$, with family income between two and four minimum wages (66.67\%) and ages between 20 and 40 years old (73.05\%). Turning now to professional category, we see that most of the subjects of the research are nursing technicians $(61.70 \%)$. Table 1 shows the absolute and relative frequency of the characteristics as mentioned here, providing a first recognition of the population studied.

Table 1 - Frequency of the social and demographic characteristics of the nursing professional at the $\mathrm{Dr}$ Antônio Fontes Regional Hospital and the São Luiz Hospital in Cáceres, State of Mato Grosso, Brazil, 2010

\begin{tabular}{|c|c|c|}
\hline Variable & $\mathbf{N}$ & $\%$ \\
\hline \multicolumn{3}{|l|}{ Sex } \\
\hline Female & 119 & 84.40 \\
\hline Male & 22 & 15.60 \\
\hline \multicolumn{3}{|l|}{ Marital Status } \\
\hline Single & 49 & 34.75 \\
\hline Married & 82 & 58.15 \\
\hline Others & 10 & 7.10 \\
\hline \multicolumn{3}{|l|}{ Children } \\
\hline With children & 34 & 24.10 \\
\hline Childless & 107 & 75.90 \\
\hline \multicolumn{3}{|l|}{ Family Income } \\
\hline 2 to 4 minimum wages & 94 & 66.67 \\
\hline 5 to 10 minimum wages & 46 & 32.62 \\
\hline Not Informed & 01 & 0.71 \\
\hline \multicolumn{3}{|l|}{ Age Bracket } \\
\hline $20-40$ years old & 103 & 73.05 \\
\hline $41-60$ years old & 31 & 21.99 \\
\hline Not Informed & 7 & 4.96 \\
\hline \multicolumn{3}{|l|}{ Professional Category } \\
\hline Nurse & 30 & 21.30 \\
\hline Technician & 87 & 61.70 \\
\hline Assistant & 24 & 17.00 \\
\hline Total & 141 & 100.00 \\
\hline
\end{tabular}

The worker who works in hospital institutions is exposed to different factors of occupational stress that have a direct bearing on their well-being. For this reason, the presentation of such information as the working day, workload, double employment and others becomes relevant when we are talking about the Burnout Syndrome. Table 2 shows the information regarding work characteristics, that shall later be analysed in order to get to know their relationship with the Burnout Syndrome.

Table 2 - Frequency of work characteristics among the professional people working in the nursing sector at Dr Antônio Fontes Regional Hospital and the São Luiz Hospital in the city of Cáceres, State of Mato Grosso, Brazil, 2010

\begin{tabular}{|c|c|c|}
\hline Variables & $\mathbf{N}$ & $\%$ \\
\hline \multicolumn{3}{|l|}{ Work Regime } \\
\hline By the Day & 58 & 41.13 \\
\hline Rota system & 70 & 49.65 \\
\hline Not informed & 13 & 9.22 \\
\hline \multicolumn{3}{|l|}{ Workload } \\
\hline 40 hours & 119 & 84.40 \\
\hline 30 hours & 9 & 6.38 \\
\hline Not informed & 13 & 9.22 \\
\hline \multicolumn{3}{|c|}{ Type of contract of employment } \\
\hline Statutory & 40 & 28.37 \\
\hline Temporary Contract & 89 & 63.12 \\
\hline Not informed & 12 & 8.51 \\
\hline \multicolumn{3}{|l|}{ Double employment } \\
\hline Yes & 37 & 26.24 \\
\hline No & 90 & 63.83 \\
\hline Not informed & 14 & 9,93 \\
\hline \multicolumn{3}{|l|}{ Time Qualified } \\
\hline Up to 5 years & 48 & 34.04 \\
\hline 6 years & 90 & 63.83 \\
\hline Not informed & 3 & 2.13 \\
\hline \multicolumn{3}{|l|}{ Time working at the unit } \\
\hline Less than 1 year & 26 & 18.44 \\
\hline 1 to 5 years & 53 & 37.59 \\
\hline More than 5 years & 51 & 36.17 \\
\hline Not informed & 11 & 7.80 \\
\hline \multicolumn{3}{|l|}{ Sector of Work } \\
\hline Administrative & 5 & 3.55 \\
\hline Open & 86 & 60.99 \\
\hline Closed & 46 & 32.62 \\
\hline Not Informed & 4 & 2.84 \\
\hline Total & 141 & 100 \\
\hline
\end{tabular}

Taking the work regime into account, we can see that 70 of the interviewed subjects operate on a call-out system $(49.65 \%)$ while $58(41.13 \%)$ are daily workers. Here we must mention that the former group comprises those workers who work according to a rota system to carry out their weekly workload, without necessarily being present every day at the unit, or even at the same time. In the case of the daily workers there is no such mobility in terms of days and times worked.

Results show that 119 (84.40\%) of the professional interviewed work a 40 -hour week and nine interviewees 
(6.38\%) work thirty hours a week, which corresponds to six hours a day, distributed in shifts.

In terms of the employment relationship of the professional people under study, we see that $40(28.37 \%)$ of the professionals are statutory civil servants and $89(63.12 \%)$ have a temporary contract of employment under the terms and conditions of the Brazilian Consolidated Labour Laws (Consolidação das Leis do Trabalho - CLT) and a Statutory Regime according to the Secretariat for Health of the State of Mato Grosso (SES/MT), which reveals the influence of temporary contracts on health institutions.

Out of the professional people surveyed, 37 (26.24\%) have two jobs, while 90 professionals $(63.83 \%)$ do not work anywhere else. Among those who have additional employment, all have the same job in the health sector except for one who also works as a teacher. We see that for this variable there is a predominance of professional people who do not have additional employment.

In terms of the qualification time of these professionals in the nursing field, 48 (34.04\%) have been working in the field for up to five years, while 90 $(63.83 \%)$ have six or more years of professional activity. In relation to the time working at the particular unit, we see that $51(36.17 \%)$ have been working there for at least five years.

Regarding the distribution of professional people among the different segments, first we must stress that the classification of the units of activity of the nursing team has considered a division into three sectors: administrative, open sector and closed sector. The administrative sector includes professionals working in management or supervision roles, which in this case is the committee for controlling hospital infection (CCIH) and co-ordination of the nursing activities of the hospital. In the open segment, the professionals who act in the inpatient treatment units: general clinical and surgical activities, an obstetrics clinic and paediatrics. In closed areas we have those professionals working in the intensive care unit (ICU), the surgical centre, and also the centre for storage of materials and sterilisation $(\mathrm{CME})$, and also in relation to the term administrative sector, as we understand that the professional people who work in management and supervision also perform such functions.
The results of the present study show that five $(3.55 \%)$ professional people were in administrative roles, $86(60.99 \%)$ in open sectors and $46(32.62 \%)$ in closed sectors.

On observing the work variables it is possible to characterise the population as studied as being, mostly, people working to a rota system, 40 hours per week, in a range of different sectors, with a temporary contract and only one contract of employment, who have been qualified and working in the area for more than five years.

The Burnout Syndrome, as we have seen, is a condition involving psychic suffering, related to work. In Table 3, to follow, we find the incidence of Burnout Syndrome related to certain work aspects.

In terms of work regime, the daily workers had a greater prevalence of the syndrome ( 9 - 15.5\%) compared with those working to a rota system.

We also see that the greatest incidence related to weekly workload with Burnout Syndrome was shown among the professional people who work to a working week of 30 hours $(22.2 \%)$ when compared with those working 40 hours weekly (9.2\%).

In relation to the most common values of MBI related to employment bond, ten $(11.2 \%)$ of the cases of the Syndrome that were found refer to professional people with temporary contracts based on the CLT.

The nursing professionals that have more than one job - a double employment bond - had a greater frequency $(13.5 \%)$ when compared to those that do not have any other relationship of employment $(8.88 \%)$, with $\rho=0,434$.

In relation to the distribution of Burnout when it comes to time of qualification, the professional that are most afflicted are those who have been qualified between zero and five years $(6-12.5 \%)$. In relation to duration of employment, $15.4 \%$ of all cases of Burnout occur in professional people who have been working less than a year. In relation to the classification of work sectors, we see that the occurrence of Burnout among the professionals based in the administrative segment was $40.0 \%$. There was a statistically significant difference between the administrative segment and the open sectors $(p=0.01)$ and also between the administrative sector $\mathrm{x}$ closed sectors $(\rho=0.039)$. 
Table 3 - Occurrence of Burnout Syndrome according to certain work aspects of the nursing professional at the Dr Antônio Fontes Regional Hospital and the São Luiz Hospital in the city of Cáceres, State of Mato Grosso, Brazil, 2010

\begin{tabular}{|c|c|c|c|c|c|c|c|}
\hline \multirow{2}{*}{ Variables } & \multicolumn{2}{|c|}{ Burnout } & \multirow{2}{*}{$\% \mathrm{MBI}^{*}$} & \multirow{2}{*}{$\mathbf{R P}^{\dagger}$} & \multirow{2}{*}{$\mathrm{Cl}^{\ddagger}(95 \%)$} & \multirow{2}{*}{$x^{2 \S}$} & \multirow{2}{*}{$\rho$-value } \\
\hline & Yes & No & & & & & \\
\hline \multicolumn{8}{|l|}{ Work regime } \\
\hline Daily worker & 9 & 49 & 15.5 & & & & \\
\hline Rota system & 4 & 66 & 5.7 & & & & \\
\hline Not informed & - & 13 & & & & & \\
\hline Daily x Rota & & & & 2.72 & $0.88-8.37$ & 3.34 & 0.067 \\
\hline Total & 13 & 128 & & & & & \\
\hline \multicolumn{8}{|l|}{ Working week } \\
\hline 40 hours & 11 & 108 & 9.2 & & & & \\
\hline 30 hours & 2 & 7 & 22.2 & & & & \\
\hline Not informed & - & 13 & & & & & \\
\hline $40 \times 30$ hours & & & & 0.42 & $0.11-0.6$ & 1.54 & 0.213 \\
\hline Total & 13 & 128 & & & & & \\
\hline \multicolumn{8}{|l|}{ Employment Bond } \\
\hline Statutory & 3 & 37 & 7.5 & & & & \\
\hline Contract & 10 & 79 & 11.2 & & & & \\
\hline Not informed & - & 12 & & & & & \\
\hline Statutory $\mathrm{X}$ Contract & & & & 0.67 & $0.19-2.30$ & 0.43 & 0.514 \\
\hline Total & 13 & 128 & & & & & \\
\hline \multicolumn{8}{|l|}{ Double Employment } \\
\hline Yes & 5 & 32 & 13.5 & & & & \\
\hline No & 8 & 82 & 8.88 & & & & \\
\hline Not informed & - & 14 & & & & & \\
\hline Yes X No & & & & 1.52 & $0.53-4.34$ & 0.61 & 0.434 \\
\hline Total & 13 & 128 & & & & & \\
\hline \multicolumn{8}{|l|}{ Qualification Time } \\
\hline 0 to 5 years & 6 & 42 & 12.5 & & & & \\
\hline 6 years or more & 4 & 86 & 4.4 & & & & \\
\hline Not informed & 3 & - & & & & & \\
\hline 0 to 5 years $X \geq 6$ years & & & & 2.81 & $0.83-9.49$ & 3.02 & 0.082 \\
\hline Total & 13 & 128 & & & & & \\
\hline \multicolumn{8}{|l|}{ Time working at the unit } \\
\hline$<1$ year & 4 & 22 & 15.4 & & & & \\
\hline 1 to 5 years & 6 & 47 & 11.3 & & & & \\
\hline$\geq 5$ years & 3 & 48 & 5.88 & & & & \\
\hline Not informed & - & 11 & & & & & \\
\hline$<1$ year $X 1$ to 5 years & & & & 1.36 & $0.42-4.40$ & 0.26 & 0.609 \\
\hline Total & 13 & 128 & & & & & \\
\hline \multicolumn{8}{|l|}{ Sector } \\
\hline Administrative & 2 & 3 & 40 & & & & \\
\hline Open & 6 & 80 & 6.97 & & & & \\
\hline Closed & 5 & 41 & 2.85 & & & & \\
\hline Not informed & - & 4 & & & & & \\
\hline Adm X open & & & & 5.73 & $1.53-21.51$ & 6.43 & 0.011 \\
\hline Adm $X$ closed & & & & 4.60 & $1.11-19.12$ & 4.26 & 0.039 \\
\hline Total & 13 & 128 & & & & & \\
\hline
\end{tabular}

* \% MBI - Percentage of syndrome; † RP - Prevalence Ratio; ₹ CI - Confidence Interval; § x2 - Chi Square Hypothesis Test; II p-value - significance.

\section{Discussion}

As previously observed, care was taken to limit the Syndrome in relation to work factors, so that it could be possible to observe the degree of significance between one variable and the unfolding thereof.

The results obtained in the research made it evident that, in the sample studied, the working hours of most 
of the professionals (84.40\%) is 40 hours per week. However, the professionals with greatest occurrence of the Burnout Syndrome are those who work to a working week of 30 hours.

In agreement with the results found, a certain study ${ }^{(14)}$ also found that the nurses with the highest number of deviations in Burnout dimensions had a lower workload, as professionals working less time in an institution end up having two jobs, as in this they see the possibility of increasing the family income. As some authors have shown (15-16), this overload of work is one of the factors that trigger Burnout. It is therefore essential to think and also develop new studies about this variable to better understand its relationship with the health/illness process.

In terms of employment bond, we see that $63.12 \%$ of the nursing professionals only have a temporary contract with the institution, and that these hired professional people are also the ones with the highest occurrence of the Syndrome. As a rule, the fact that the worker is hired tends to make him or her anxious every time the contract ends, wanting to know if there shall be a renewal or not. The fact that he or she is hired leads to a concern with keeping his or her job, to honour their financial commitments and also to ensure the sustainability of the family. The condition of stability at work gives the professional person some peace of mind when the contract ends and also in relation to unemployment. This aspect should be taken into account as personal satisfaction, but it is well known that at the Regional Hospital, which is a state-run Government institution, even today there is a high number of temporary contracts, while in the São Luiz Hospital, which is privately owned with partnership agreements, all the personnel is hired.

Equivalent to what was found in our research, another study(17) brings the difference found when comparing the professional people with more stable career situations (those with regular employment at the place of work) and professionals with more unstable contractual situations (temporary contracts), with the syndrome being more common in this latter case. Another author ${ }^{(18)}$ also points out that this data is backed up by the contractual situation, as the people in temporary employment in their respective places of work tend to have more stress associated with professional and career instability.

With regard to double employment, the results show that the majority $(63.83 \%)$ of the professional in the nursing sector at these two hospitals studied do not have other jobs. When the relationship between this variable and the syndrome is studied, we see there is no significant difference. The fact that the professional has multiple jobs, a reality which is quite common in the nursing profession, could intensify the absenteeism problem.

In a certain study, the author ${ }^{(19)}$ describes the fact that the professional people in this area see themselves under pressure to often have two or three jobs due to the extremely low salaries, which are incompatible with the dignity of their activities, these being facts that have been worsening the quality of life of these workers, leading them to have more than one job to increase the family income, which means long working days, stress, and not much time for leisure and for the family.

In another study, a certain author ${ }^{(20)}$ reports that the accelerated pace of work, resulting from the always insufficient number of workers and also the excess of tasks per individual, which require accelerated execution of activities and reduction of pausing times. In addition, this pace steps up even further when the worker has two jobs, as this situation is probably repeated in both jobs.

On analysing the qualification time, we saw that the professionals who have been qualified between zero and five years are those most prone to the Burnout Syndrome. Thus, the short time on the job, according to the results, is influencing the health of the worker, which can jeopardise the quality of the activities thus developed. In most cases, the act of leaving University and entering the labour market, in a variety of occupations, can generate stress in the individual.

Other studies have shown (21-22) that workers with little professional experience have greater likelihood of developing the symptoms, feeling poorly prepared for the responsibilities of the profession. A certain study ${ }^{(2)}$ has reported that Brazilian nursing professionals who are starting their careers could be frustrated with their work, and hence have a feeling of alienation, mainly because they have an unrealistic understanding of the scope and the limits of their practices.

In relation to the location sector, the results show that the professional people who work in the administrative segment are the most affected by the symptoms (40\%). Within the administrative universe, the nurse responsible makes a direct job of responding to the Resolutions requested by the Nursing Council and also responsibilities set by a superior body, meaning that the levels of demands bring the professional person a package of conditions which could lead to the Burnout Syndrome. Closed environments are full of responsibilities and tasks that lead the professional 
person to have significant influence of stress-causing factors.

\section{Conclusion}

With the present study, we have analysed the wearing-out process among professional people of the nursing segment, from different hospital sectors, thereby offering a view of the taking ill of these workers. We have seen that, in the case of the two hospitals of the city of Cáceres, State of Mato Grosso, the nursing professionals most affected by Burnout Syndrome are those who have fixed working days, working a 30hour week, with a contract of employment, double employment, less time as qualified professionals, who have been working at the unit less than one year, and those who work in the administrative area.

We have also stressed some of the work aspects related to the hospital as a working environment, which interfere with the quality of life of nursing professionals. So here we highlight the need to propose organisational changes in the working environment, in order to reduce these factors which end up affecting the workers' health. Work must not be a heavy burden, and at the same time must not be a cause for discomfort or misfortune. On the contrary, it should offer the people conditions for development of their full potential and self-fulfilment.

We hope that this study raises concerns with regard to this issue, and that these, in turn, generate new discussions and research in the field, and thus make a contribution not only towards the acknowledgement of Burnout in nursing teams, but also towards the increase of conscientious concern on the part of all those involved, with the quality of life of our nursing professionals.

\section{References}

1. Ballone GJ. Síndrome de Burnout. PsiqWeb Psiquiatria Geral [Internet]. 2010 [acesso 28 dez 2011]. Disponível em: //http://www.psiqweb.med.br/cursos/stress4.html.

2. Carlotto MS, Palazzo LS. Síndrome de Burnout e fatores associados: um estudo epidemiológico com professores. Cad Saúde Pública. 2006;22(5):1017-26.

3. Ferrari R, França FM, Magalhaes J. Avaliação da síndrome de burnout em profissionais de saúde. Gestão e Saúde. In press 2012.

4. Carlotto MS, Camara SG. Análise fatorial do Maslach Burnout Inventory (MBI) em uma amostra de professores de instituições particulares. Psicol Estud. 2004;9(3):499-505.
5. Lorenz VR, Benatti MCC, Sabino MO. Burnout e estresse em enfermeiros de um hospital universitário de alta complexidade. Rev. Latino-Am. Enfermagem. 2010;18(6):1084-91

6. Rossini AB, Carlotto S. Síndrome de Burnout em monitores de uma fundação de proteção especial. Rev Diversitas - Perspect Psicol. 2007;4(1):53-62.

7. Moreira DS, Magnago RF, Sakae TM, Magajewski FRL. Prevalência da síndrome de Burnout em trabalhadores de enfermagem de um hospital de grande porte da Região Sul do Brasil. Cad Saúde Pública. 2009;25(7):1559-68. 8. Murofuse NT, Abranches SS, Napoleão AA. Reflexões sobre estresse e Burnout e a relação com a enfermagem. Rev. Latino-Am. Enfermagem.2005;13:255-61.

9. Meneghini F, Paz AA, Lautert L. Fatores ocupacionais associados aos componentes da síndrome de Burnout em trabalhadores de enfermagem. Texto ContextoEnferm. 2011;20(2):225-33.

10. França FM, Ferrari R. Estresse ocupacional crônico e o setor de atuação dos profissionais de enfermagem da rede hospitalar. Gestão e Saúde. 2012;3(1):531-45. 11. França FM, Ferrari R. Síndrome de Burnout e os aspectos sócio-demográficos em profissionais de enfermagem. Acta paul Enferm. In press 2012.

12. Peron C. O papel da auditoria frente ao pacto de gestão do Sistema Único de Saúde. [Pós-graduação] Cuiabá: Escola de Saúde Pública; 2007.

13. Tamayo RM. Relação entre a síndrome de burnout e os valores organizacionais no pessoal de enfermagem de dois hospitais públicos [Dissertação de Mestrado]. Brasília: Instituto de Psicologia, Universidade de Brasília 1997.

14. Santos $F E$, Joubert $A A$, Rodrigues $A B$. Síndrome de Burnout em enfermeiros atuantes em uma Unidade de Terapia Intensiva. Einstein. 2009;7(1):58-6.

15. Amaro HJF. Comportamentos Comunicacionais Assertivos e Burnout nos Profissionais de Enfermagem. Rev Nursing. 1996;221:7-16.

16. Nascimento ABE. Síndrome de Burnout. Rev Psiquiatr Clin. 2001;28(6):347-9.

17. Silva MCM, Gomes ARS. Stress ocupaciona em profissionais de saúde: um estudo com médicos e enfermeiros portugueses. Estud Psicol. 2009;14(3):239-48.

18. Gomes AR, Cruz JF, Cabanelas S. Estresse ocupacional em profissionais de saúde: um estudo com enfermeiros portugueses. Psicologia: Teor Pesq. 2009;25(3):307-18. 19. Silva FPP. Burnout: um desafio à saúde do trabalhador. Rev Psicol Soc Instituc.[periódico na Internet]; 2000; 
[acesso 13 out 2011]. 2(1). Disponível em: http://www. uel.br/ccb/psicologia/revista/textov2n15.htm

20. Mininel VA, Baptista PCP, Felli VEA. Psychic workloads and strain processes in nursing workers of Brazilian university hospitals. Rev. Latino-Am. Enfermagem. 2011;19(2):340-7.

21. Martinez J. Aspectos epidemiologicos del síndrome de burnout em personal sanitário. Rev Esp Salud Pública. 1997;71:293-303.

22. Schaufe WB, Toppinnen S, Kalimo R, Schutte IN. The factorial validity of the Maslach Burnout Inventory General Survey across occupational groups and nations. J Occup OrganPsychol. 2000;73:56-66. 